\title{
DISTRIBUTIONAL CHANGES OF LANDBIRD SPECIES IN AGROECOSYSTEMS OF CENTRAL ARGENTINA
}

\author{
Mariano Codesido $^{1,2,3}$ CARlos González-Fischer $^{1,2}$, And David Bilenca ${ }^{1,2}$ \\ ${ }^{1}$ Grupo de Estudios sobre Biodiversidad en Agroecosistemas (GEBA), Facultad de Ciencias Exactas y Naturales, \\ Universidad de Buenos Aires, Intendente Güiraldes 2160, Ciudad Universitaria, \\ Pabellón II, Buenos Aires C1428EGA, Argentina \\ ${ }^{2}$ Consejo Nacional de Investigaciones Cientificas y Técnicas (CONICET), Av. Rivadavia 1917, \\ Buenos Aires C1033AAJ, Argentina
}

\begin{abstract}
We present the first quantitative comparative study between current (2006-2008) distributions of landbird and those recorded prior to the massive planting of transgenic soy beans in the Pampas of central Argentina (Narosky and Di Giacomo 1993). We surveyed landbirds along transects covering 23 counties of Buenos Aires province. To allow a comparison between our observations and those of Narosky and Di Giacomo, we used the number of counties in which each species was recorded as an estimate of current and past distributions. We found grassland and wetland specialists in significantly fewer counties than did Narosky and Di Giacomo $(P<0.05)$, while habitat generalists and woodland specialists showed no significant change. The earlier study, however, covered a longer period of time, which could explain the reduction of wetland dwellers as a result of variation in the supply of temporary water bodies. The decreased area of occupancy of grassland specialists, on the other hand, may reflect the reduction of native grasslands due to increased agricultural cultivation, particularly in the Rolling Pampa, where agricultural expansion has left few remnant grasslands and we did not detect three formerly common grassland specialists, Hymenops perspicillatus, Embernagra platensis, and Pseudoleistes virescens. These findings emphasize the need for conservation actions to support populations of grassland bird in the Pampas.
\end{abstract}

Keywords: agricultural intensification, agroecosystem, grassland birds, Pampas, Argentina.

\section{Cambios en la Distribución de Especies de Aves Terrestres en Agroecosistemas del Centro de Argentina}

Resumen. Ofrecemos el primer estudio cuantitativo comparado de las distribuciones actuales de especies de aves terrestres (2006-2008) con respecto a las distribuciones conocidas para dichas especies en la Pampa del centro de Argentina antes de la introducción masiva de cultivos de soja transgénica en la región (Narosky y Di Giacomo 1993). Los muestreos de aves terrestres fueron conducidos a lo largo de transectas que cubrieron 23 partidos de la provincia de Buenos Aires. Para poder comparar nuestras observaciones con las correspondientes al estudio de Narosky y Di Giacomo, usamos el área de ocupación (número de partidos) en el cual cada especie fue registrada como una estimación de su rango de distribución presente y pasado. Las aves especialistas de pastizales y de humedales fueron registradas en un menor número de partidos que con respecto al estudio de Narosky y Di Giacomo $(P<0.05)$; no se registraron cambio significativos en la distribución de las aves generalistas de hábitat ni en las especialistas de arboleda. Debe destacarse que los datos acumulados en el estudio de Narosky y Di Giacomo cubrieron un lapso de tiempo más extenso que nuestro estudio, de modo que la reducción observada en el área de ocupación de las especialistas de humedales simplemente podría reflejar la menor oferta y distribución de cuerpos temporales de agua requeridos por estas especies durante el breve período cubierto por nuestro estudio. Por el contrario, la reducción observada en el área de ocupación de las especialistas de pastizales podría reflejar la retracción de los pastizales naturales como resultado del aumento de la cobertura de los cultivos anuales, en particular para la Pampa Ondulada, donde la extensión agrícola ha dejado pocos pastizales remanentes, y tres especialistas de pastizales anteriormente comunes (Hymenops perspicillatus, Embernagra platensis y Pseudoleistes virescens) no fueron registradas en nuestros muestreos. Estos resultados demuestran la necesidad de impulsar acciones concretas de conservación sobre las especies de pastizales de la Pampa Argentina.

Manuscript received 2 October 2009; accepted 3 December 2010.

${ }^{3}$ E-mail: mcodesido@ege.fcen.uba.ar

The Condor, Vol. 113, Number 2, pages 266-273. ISSN 0010-5422, electronic ISSN 1938-5422. (C) 2011 by The Cooper Ornithological Society. All rights reserved. Please direct all requests for permission to photocopy or reproduce article content through the University of California Press's Rights and Permissions website, http://www.ucpressjournals.com/ reprintInfo.asp. DOI: 10.1525/cond.2011.090190 


\section{INTRODUCTION}

Agricultural practices have led to changes in land-use patterns and landscape structure worldwide (Aide and Grau 2004, Foley et al. 2005), affecting the biodiversity of rural landscapes and causing the decline of many species (Donald et al. 2001, 2006, Benton et al. 2003, Askins et al. 2007). Bird assemblages are sensitive to such changes, even though each species may respond differently, depending on its life history and degree of habitat specialization (Warner 1994, McLaughlin and Mineau 1995, Robinson and Sutherland 2002, BirdLife International 2004, Rodríguez-Estrella 2007, Herzon et al. 2008).

Land-use practices in the Pampas of central Argentina have modified the original grasslands in a relatively short period (Soriano et al. 1991, Krapovickas and Di Giacomo 1998, Ghersa and León 1999, Bilenca and Miñarro 2004). Crops were introduced $\sim 150$ years ago and quickly became a major disturbance factor. By the beginning of the 20th century, several specialized grassland birds reported from Buenos Aires province by early naturalists (Doering and Lorentz 1879, Barrows 1883, Holmberg 1883/1884) had already experienced range shifts in the region. Species exemplifying these shifts include the Saffron-cowled Blackbird (Xanthopsar flavus; Fraga et al. 1998) and the Strange-tailed Tyrant (Alectrurus risora; Di Giacomo and Di Giacomo 2004; see also Di Giacomo et al. 2007, BirdLife International 2008, Codesido and Fraga 2009), which used to occur in Buenos Aires province but are now restricted to the grasslands of northern Argentina. In Buenos Aires province, the distributions of other grassland birds, like the Pampas Meadowlark (Sturnella defilippii; Tubaro and Gabelli 1999, Fernandez et al. 2003) and the Black-and-white Monjita (Heteroxolmis dominicanus; Fraga 2003), have also contracted considerably. On the other hand, the introduction of trees in the Pampas around houses and as woodlots to shade cattle was followed by the expansion of species such as the Rufous Hornero (Furnarius rufus) and the Monk Parakeet (Myiopsitta monachus), among others (Daguerre 1936).

During the last two or three decades, cattle and sheep raising in the Pampas has been progressively restricted to marginal areas, and natural rangelands and pastures have been replaced by crops (Baldi and Paruelo 2008). Agricultural expansion has been led by the soybean (Glycine max), which quickly became the region's main crop (Aizen et al. 2009). In 1996, a transgenic cultivar of soybean resistant to glyphosate was introduced on the market and rapidly adopted by farmers, greatly increasing the area planted with soybean (MartínezGhersa and Ghersa 2005, Aizen et al. 2009).

The effects on biodiversity of these recent changes in agricultural practices have stimulated new studies in Argentina (Bilenca et al. 2007, Filloy and Bellocq 2007, Codesido et al. 2008, Schrag et al. 2009). A program of monitoring species richness of birds across a vast region covering part of the phytogeographic provinces of the Pampas and the Espinal savanna showed that the number of species was positively correlated with cover of native vegetation and negatively correlated with agricultural use (Schrag et al. 2009). In the Pampas, the abundance of 20 species was significantly correlated with the percentage of cropland. Responses were mostly negative but some were positive responses of bird populations to increasing intensity of crop production along an agricultural gradient (Filloy and Bellocq 2007).

In spite of these new insights about the effects of agricultural practices on the avifauna of the Pampas, there are no studies comparing changes in bird assemblages with baseline data, probably because this kind of information is lacking for many parts of the Pampas (Schrag et al. 2009). However, a comprehensive study with records of bird distributions prior to these recent changes in agricultural practices is available for Buenos Aires province in central Argentina, allowing for a comparison of at least this part of the Pampas (Narosky and Di Giacomo 1993). In this paper, we present the first quantitative comparative study of current (2006-2008) distributions of land birds in relation to those recorded prior to the massive planting of transgenic soy beans in Buenos Aires province (1938-1993; Narosky and Di Giacomo 1993), and we discuss how changes in bird communities may be linked to documented changes in land-use practices during the interval between these two studies.

\section{METHODS}

\section{STUDY AREA}

Our study focused on three ecological units within the Pampas of Buenos Aires province $\left(307571 \mathrm{~km}^{2}\right)$, in central Argentina, the Rolling, Flooding, and Southern Pampas, which differ in geomorphology, soil, drainage, physiography, and vegetation (León $1991,33^{\circ}-41^{\circ} \mathrm{S}$ and $57^{\circ}-63^{\circ} \mathrm{W}$; Fig. 1a). These units also differ in land-use patterns (LART-MAAyP 2004; Fig. 1a): whereas agriculture has replaced more than $75 \%$ of the native vegetation in the Rolling Pampa, most of the Flooding Pampa remains as grassland (>85\%). In the Southern Pampa the production system is have a mixed agriculture and animal husbandry. In the Rolling Pampa, summer crops [soybean and maize (Zea mays)] are predominant, whereas in the Southern Pampa winter crops, i.e., wheat (Triticum aestivum) prevail (INDEC 2006). The region's mean annual temperature varies from $13{ }^{\circ} \mathrm{C}$ in the south to $17{ }^{\circ} \mathrm{C}$ in the north; its mean annual precipitation averages $\sim 950 \mathrm{~mm}$ (Fig. 1b).

\section{BIRD SAMPLING}

We surveyed for land birds along 18 transects lying along secondary and tertiary roads (six transects in each ecological unit) covering 23 partidos or counties of Buenos Aires province. Each transect was $20 \mathrm{~km}$ long, with permanently marked 


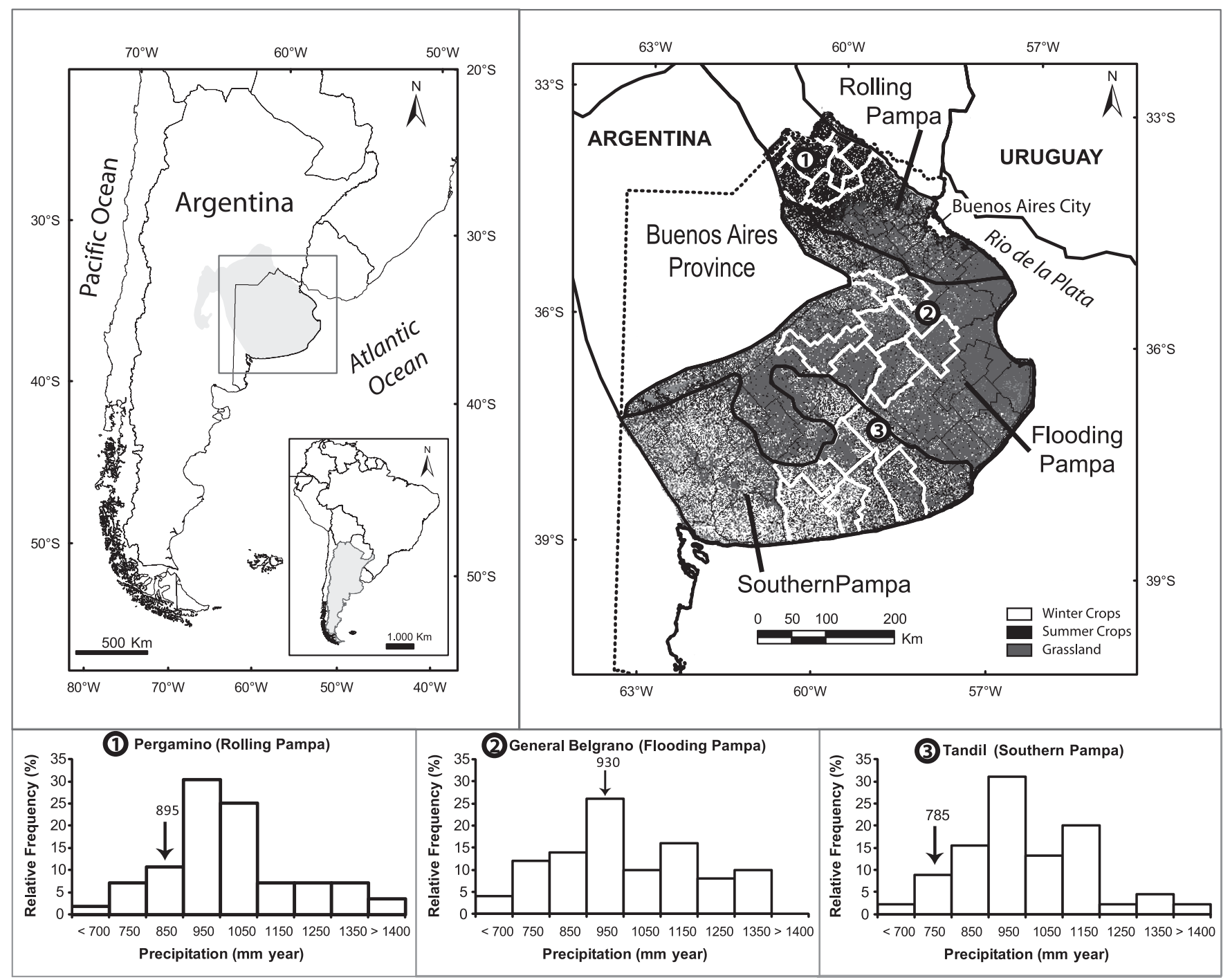

FIGURE 1. Detail of the study area (Buenos Aires province, Argentina) indicating (a) land-use cover types and limits of both the counties included in our comparative study and the ecological units considered in our analysis (Rolling Pampa, Flooding Pampa and Southern Pampa), and (b) histograms with annual rainfall recorded 1938-1993 at three locations: Pergamino (Rolling Pampa), General Belgrano (Flooding Pampa), and Tandil (Southern Pampa); arrows indicate average annual rainfall during our bird surveys (2006-2008). Land-use cover extracted from LART-MAAyP (2004); rainfall data provided by the Servicio Meteorológico Nacional.

survey points located every kilometer. The same observer (MC) sampled each transect with point counts (Bibby et al. 2000) four times between 2006 and 2008, twice in summer during the austral breeding season (January-February) and twice in winter, during the nonbreeding season (July-August). Counts were carried out in the morning, $3 \mathrm{hr}$ after dawn, and in the evening, during the last $3 \mathrm{hr}$ before sunset. For $5 \mathrm{~min}$, all land birds seen or heard within a 200-m radius around each point were identified and counted, resulting in a sampling effort of $7200 \mathrm{~min}$ (1440 point counts). We categorized all species as either habitat specialists (i.e., species that nest exclusively in grasslands, wetlands, woodlands, croplands, or peridomestic areas) or habitat generalists (species that nest in more than one habitat), according to Narosky et al. (1983), Narosky and Salvador (1998), de la Peña (2005), and Cozzani and Zalba (2009).

\section{DATA ANALYSIS}

We compared our bird-distribution data with baseline data reported by Narosky and Di Giacomo (1993), who provided distributional data for each species within the province of Buenos Aires at the level of the county. Narosky and Di Giacomo compiled data from 1938 to 1993 on the basis of personal observations, published sources, museum specimens, 
and field reports provided by experienced birdwatchers. To compare our observations with the results of Narosky and Di Giacomo, we used the number of counties in which each species occurs as an estimate of its area of occupancy (Gaston 1994), reflecting the current and past range of each species in the study area.

Given that our methods and those of Narosky and Di Giacomo differ in several aspects, we took precautions so that comparisons of the two datasets would be valid (Peh 2007). First, we restricted our comparative analyses to resident land birds, excluding migratory species whose distributions among years may be variable and opportunistic (Peh 2007). Next, we considered only species categorized as "abundant" or "common" by Narosky and Di Giacomo. The exclusion of rare species allowed us to avoid the problems involved with detecting rare species (Peh 2007). Abundant and common species are easily observed in agroecosystems, so the bias for these species should be minimal (Møller and Jennions 2001) and the distributional data obtained from Narosky and Di Giacomo should be reliable. In addition, our sampling within each county ( $>200 \mathrm{~min}$ ) was sufficient to reveal $>95 \%$ of all common or abundant land birds (M. Codesido, unpubl. data), also providing reliable data on the presence of these species in each county.

To estimate general changes in the area of occupancy, we computed the absolute difference in the number of counties in which each species was recorded by us and by Narosky and Di Giacomo. Then, for each category of nesting birds (i.e., generalists, grassland, wetland, and woodland species), we compared the number of counties with the Wilcoxon test for paired samples (Siegel and Castellan 1988).

\section{RESULTS}

We detected all of the 49 resident species of land birds recorded as abundant or common by Narosky and Di Giacomo in at least one ecological unit covered by our surveys (Table 1). The number of common and abundant species we found in each year and ecological unit remained similar. We recorded 45 species in the Rolling Pampa (44 in 2006/2007 and 41 in 2007/2008), 46 in the Flooding Pampa (45 in 2006/2007 and 44 in 2007/2008), and 46 in the Southern Pampa (45 in 2006/2007 and 45 in 2007/2008). Despite the similarity in the total number of species in each habitat, some common species reported by Narosky and Di Giacomo were absent from certain ecological units, according to our sampling. The Spectacled Tyrant (Hymenops perspicillatus), Great Pampa-Finch (Embernagra platensis), and Brown-and-Yellow Marshbird (Pseudoleistes virescens) are grassland specialists reported by Narosky and Di Giacomo as common in all ecological units. In our surveys these species were absent from the Rolling Pampa, the unit with the region's most intensive agriculture. Similarly, we did not detect the Maguari Stork (Ciconia maguari) in the Southern Pampa (Table 1). These four species are conspicuous by coloration, voice, and behavior and unlikely to be overlooked (Rodríguez Mata et al. 2006, Ridgely and Tudor 2009).

According to our classification system, most species of land birds in the study area's rural landscape nest in woodlots, in peridomestic areas, and in grasslands (Table 2), but neither cropland nor domestic areas is the exclusive nesting habitat of any species, and we categorized most species of land birds $(n=33)$ as generalists in their nesting habitat. Our classification of habitat specificity showed that grasslands hold the highest number of habitat specialists $(n=8)$, followed by wetlands $(n=5)$, and woodlands $(n=3)$.

Several changes in the distributions of land bird species were evident from our comparison with the report of Narosky and Di Giacomo: we found 25 species in fewer counties than they occupied in the past (Table 1), 14 species in more counties, and 10 species in the same number. Grassland and wetland specialists are present in significantly fewer counties now than reported by Narosky and Di Giacomo (Wilcoxon matched-pairs test, $z=2.03$, df $=7, P<0.05 ; z=2.02$, df. $=4$, $P<0.05$, respectively), whereas habitat generalists and woodland specialists showed no significant change in the number of counties in which they occur (Fig. 2).

\section{DISCUSSION}

This is, to the best of our knowledge, the first quantitative assessment of recent changes in the distribution of land birds in the Pampas of central Argentina. Our results agree with previous studies showing that species with higher habitat specificity are more sensitive to land-use changes (Siriwardena et al. 1998, Brook et al. 2003, Peh 2007, Azpiroz and Blake 2009, Caplat and Fonderflick 2009). In particular, our findings agree with local studies indicating that the replacement of pastoral grazing by intensive crop growing is detrimental to many bird species in the Pampas (Filloy and Bellocq 2007, Bilenca et al. 2008, Codesido et al. 2008, Schrag et al. 2009). In contrast to the situation in western Europe, which has an older history of land management (PECBMS 2009), exclusive nesting in croplands has not been reported in the agroecosystem of the Pampas.

According to our results, both grassland and wetland dwellers are experiencing a reduction in their area of occupancy across the study area. However, these results should be interpreted with caution because the datasets are based on two different studies so are subject to biases from differences in methods of data collection and determination of species' ranges (Peh 2007). The fact that the study of Narosky and Di Giacomo covers a period (1938-1993) longer than that of our study (2006-2008) could explain the reduction in the area of occupancy of wetland dwellers, merely because of the shorter supply of temporary water bodies required by these species, rather than an actual permanent geographical shift. Annual rainfall in the study area during our surveys was slightly 
TABLE 1. The 49 land birds described as "common" or “abundant” from 1938 to 1993 by Narosky and Di Giacomo (1993), categorized by nesting habitat according to Narosky et al. (1983), Narosky and Salvador (1998), de la Peña (2005), and Cozzani and Zalba (2009). An asterisk indicates the species occurs in the specified ecological unit of the Pampean Region within Buenos Aires province, Argentina, according to Narosky and Di Giacomo and this study (2006-2008). In each group the species are listed in descending order of number of counties in which each species was recorded by Narosky and Di Giacomo (1993).

\begin{tabular}{|c|c|c|c|c|c|c|c|c|}
\hline \multirow[b]{2}{*}{ Species } & \multicolumn{2}{|c|}{ Rolling Pampa } & \multicolumn{2}{|c|}{ Flooding Pampa } & \multicolumn{2}{|c|}{$\begin{array}{c}\text { Southern } \\
\text { Pampa }\end{array}$} & \multicolumn{2}{|c|}{$\begin{array}{l}\text { Number of } \\
\text { counties }\end{array}$} \\
\hline & $\begin{array}{c}1938- \\
1993\end{array}$ & $\begin{array}{c}2006- \\
2008\end{array}$ & $\begin{array}{c}1938- \\
1993\end{array}$ & $\begin{array}{c}2006- \\
2008\end{array}$ & $\begin{array}{c}1938- \\
1993\end{array}$ & $\begin{array}{c}2006- \\
2008\end{array}$ & $\begin{array}{c}1938- \\
1993\end{array}$ & $\begin{array}{r}2006- \\
2008\end{array}$ \\
\hline \multicolumn{9}{|l|}{ Grassland specialists } \\
\hline Grassland Yellow-Finch Sicalis luteola & $*$ & $*$ & $*$ & $*$ & $*$ & $*$ & 22 & 23 \\
\hline Short-eared Owl Asio flammeus & $*$ & $*$ & $*$ & $*$ & $*$ & $*$ & 21 & 7 \\
\hline Brown-and-Yellow Marshbird Pseudoleistes virescens & $*$ & & $*$ & $*$ & $*$ & * & 19 & 14 \\
\hline Long-winged Harrier Circus buffoni & $*$ & * & $*$ & $*$ & $*$ & * & 17 & 10 \\
\hline Great Pampa-Finch Embernagra platensis & $*$ & & $*$ & $*$ & $*$ & * & 17 & 15 \\
\hline Spectacled Tyrant Hymenops perspicillatus & $*$ & & $*$ & $*$ & $*$ & * & 15 & 9 \\
\hline Correndera Pipit Anthus correndera & $*$ & * & $*$ & $*$ & * & * & 14 & 16 \\
\hline Short-billed Pipit Anthus furcatus & * & * & $*$ & * & & & 7 & 4 \\
\hline \multicolumn{9}{|l|}{ Woodland specialists } \\
\hline Freckle-breasted Thornbird Phacellodomus striaticollis & * & * & & $*$ & $*$ & & 4 & 4 \\
\hline Narrow-billed Woodcreeper Lepidocolaptes angustirostris & $*$ & $*$ & & & & & 3 & 2 \\
\hline Epaulet Oriole Icterus cayanensis & $*$ & * & & & & & 3 & 1 \\
\hline \multicolumn{9}{|l|}{ Wetland specialists } \\
\hline White-faced Ibis Plegadis chihi & $*$ & * & $*$ & $*$ & $*$ & * & 23 & 19 \\
\hline Brown-hooded Gull Chroicocephalus maculipennis & * & * & $*$ & $*$ & * & * & 23 & 14 \\
\hline Cattle Egret Bubulcus ibis & $*$ & * & $*$ & $*$ & * & * & 22 & 18 \\
\hline Southern Screamer Chauna torquata & $*$ & * & $*$ & $*$ & * & * & 21 & 14 \\
\hline Maguari Stork Ciconia maguari & $*$ & $*$ & $*$ & $*$ & $*$ & & 19 & 8 \\
\hline \multicolumn{9}{|l|}{ Generalists } \\
\hline Southern Lapwing Vanellus chilensis & * & $*$ & $*$ & $*$ & $*$ & $*$ & 23 & 23 \\
\hline Field Flicker Colaptes campestris & $*$ & * & $*$ & $*$ & $*$ & $*$ & 23 & 23 \\
\hline Rufous Hornero Furnarius rufus & $*$ & * & $*$ & $*$ & $*$ & $*$ & 23 & 22 \\
\hline Chalk-browed Mockingbird Mimus saturninus & $*$ & * & $*$ & $*$ & $*$ & * & 23 & 22 \\
\hline Great Kiskadee Pitangus sulphuratus & $*$ & * & $*$ & $*$ & $*$ & $*$ & 23 & 19 \\
\hline Spotted Tinamou Nothura maculosa & $*$ & * & $*$ & $*$ & $*$ & * & 22 & 23 \\
\hline Chimango Caracara Milvago chimango & $*$ & * & $*$ & $*$ & $*$ & $*$ & 22 & 23 \\
\hline Eared Dove Zenaida auriculata & $*$ & * & $*$ & $*$ & $*$ & * & 22 & 23 \\
\hline Picazuro Pigeon Patagioenas picazuro & $*$ & * & $*$ & $*$ & $*$ & * & 22 & 23 \\
\hline House Wren Troglodytes aedon & $*$ & * & $*$ & $*$ & $*$ & $*$ & 22 & 23 \\
\hline Rufous-collared Sparrow Zonotrichia capensis & $*$ & $*$ & $*$ & $*$ & $*$ & $*$ & 22 & 23 \\
\hline Guira Cuckoo Guira guira & $*$ & * & $*$ & $*$ & $*$ & * & 22 & 22 \\
\hline Shiny Cowbird Molothrus bonariensis & $*$ & * & $*$ & $*$ & $*$ & * & 22 & 22 \\
\hline Firewood-Gatherer Anumbius annumbi & $*$ & $*$ & $*$ & $*$ & $*$ & $*$ & 22 & 18 \\
\hline Cattle Tyrant Machetornis rixosus & $*$ & * & $*$ & $*$ & $*$ & $*$ & 22 & 12 \\
\hline Monk Parakeet Myiopsitta monachus & $*$ & $*$ & $*$ & $*$ & $*$ & $*$ & 21 & 21 \\
\hline Bay-winged Cowbird Agelaioides badius & $*$ & * & $*$ & $*$ & $*$ & $*$ & 21 & 21 \\
\hline House Sparrow Passer domesticus & $*$ & * & $*$ & $*$ & $*$ & $*$ & 21 & 16 \\
\hline White-browed Blackbird Sturnella superciliaris & $*$ & * & $*$ & $*$ & $*$ & $*$ & 20 & 22 \\
\hline White-tailed Kite Elanus leucurus & $*$ & * & $*$ & $*$ & $*$ & $*$ & 20 & 21 \\
\hline American Kestrel Falco sparverius & $*$ & * & $*$ & $*$ & $*$ & $*$ & 20 & 20 \\
\hline Saffron Finch Sicalis flaveola & $*$ & * & $*$ & $*$ & $*$ & * & 20 & 19 \\
\hline Burrowing Owl Athene cunicularia & $*$ & * & $*$ & $*$ & $*$ & $*$ & 19 & 23 \\
\hline Roadside Hawk Buteo magnirostris & $*$ & * & $*$ & $*$ & $*$ & $*$ & 19 & 19 \\
\hline Green-barred Woodpecker Colaptes melanochloros & $*$ & * & $*$ & $*$ & * & * & 19 & 18 \\
\hline Rock Dove Columba livia & * & * & $*$ & * & $*$ & * & 19 & 9 \\
\hline Whistling Heron Syrigma sibilatrix & * & * & $*$ & * & * & * & 18 & 22 \\
\hline Picui Ground-Dove Columbina picui & * & * & $*$ & $*$ & $*$ & * & 17 & 11 \\
\hline Hooded Siskin Carduelis magellanica & * & * & $*$ & $*$ & $*$ & * & 15 & 14 \\
\hline Screaming Cowbird Molothrus rufoaxiliaris & * & * & $*$ & $*$ & * & * & 13 & 15 \\
\hline White-crested Tyrannulet Serpophaga subcristata & * & * & $*$ & * & * & * & 11 & 3 \\
\hline Rufous-bellied Thrush Turdus rufiventris & $*$ & * & $*$ & $*$ & $*$ & $*$ & 10 & 7 \\
\hline Long-tailed Meadowlark Sturnella loyca & & & & & $*$ & $*$ & 6 & 7 \\
\hline
\end{tabular}


TABLE 2. Nesting habitat of the generalist (which nest in more than one habitat type) and the 16 specialist (which nest in only one habitat type) species analyzed for changes in distribution in Buenos Aires province, Argentina.

\begin{tabular}{lcccccc}
\hline \hline & & \multicolumn{4}{c}{ Nesting habitat } \\
\cline { 3 - 6 } Species & Number & Grassland & Cropland & Woodland & Peridomestic & Wetland \\
\hline Generalists & 33 & 16 & 6 & 31 & 29 & 7 \\
Specialists & 16 & 8 & 0 & 3 & 0 & 5 \\
Total & 49 & & & & & \\
\hline
\end{tabular}

below the average from the period covered by Narosky and Di Giacomo (Fig. 1b), supporting this hypothesis.

On the other hand, the reduction in the area of occupancy of grassland specialists may reflect the destruction of natural and semi-natural grasslands caused by the increase in area devoted to annual crops. According to official records (INDEC 2006, Bilenca et al. 2008), more than 1200000 ha of the province of Buenos Aires was converted to agriculture between 1988 and 2002. Analyses of remotely sensed data show that conversion to agriculture has been particularly intensive in the Rolling Pampa, where grasslands had the highest annual probability of being changed to crops and the lowest probability of being abandoned once they became cultivated (Baldi and Paruelo 2008, Vega et al. 2009). Likewise, intensification of agriculture has also reduced native roadside vegetation, representing a serious setback to avian biodiversity (Speizner et al. 2007, Di Giacomo and Lopez de Casenave 2010). The expansion of agriculture in the Rolling Pampa has left few remnant grasslands, which may explain the decline of three formerly common species of grassland specialists, the

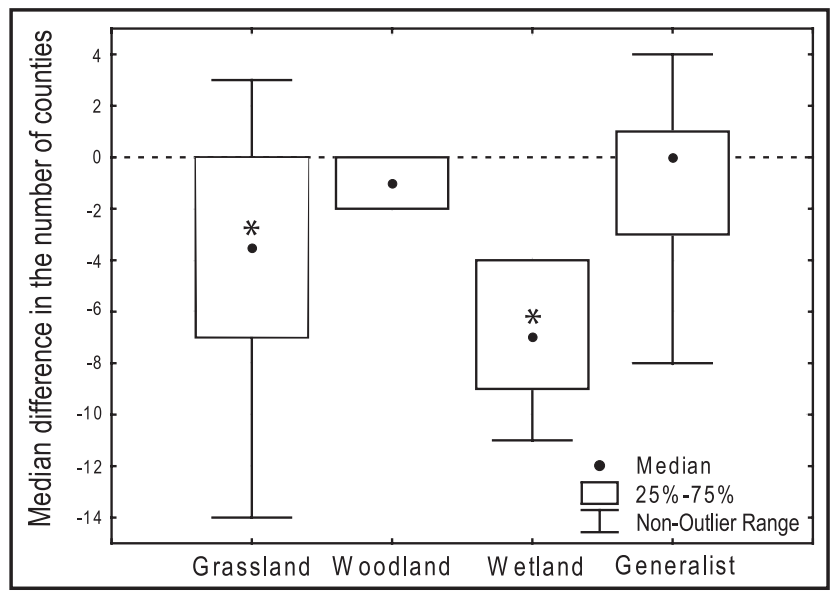

FIGURE 2. Median difference in the number of counties occupied by species of land birds according to Narosky and Di Giacomo (1993; 1938-1993) and this study (2006-2008) in Buenos Aires province, Argentina. Species are classified according to their nesting habitat: grassland specialists $(n=8)$, woodland specialists $(n=3)$, wetland specialists $(n=5)$, or generalists $(n=33)$. An asterisk indicates a significant difference between the studies in the number of counties occupied, according to a Wilcoxon test for paired samples $(P<0.05)$.
Spectacled Tyrant, the Great Pampa-Finch, and the Brownand-Yellow Marshbird, which we did not detected in this ecological unit. Our results agree with Filloy and Bellocq (2007), who also found that the abundance of these grassland specialists declined in response to the increasing area of crop cover.

\section{CONSERVATION IMPLICATIONS}

Grassland ecosystems are disappearing in the temperate zone of the Neotropical Region, a loss tied to losses of biodiversity (Vickery et al. 1999, Bilenca and Miñarro 2004, Baldi and Paruelo 2008, Vega et al. 2009). At present, $<25 \%$ of these original grasslands remain uncultivated, and the network of protected grasslands in Argentina covers $<1 \%$ of these habitats (Krapovickas and Di Giacomo 1998, Viglizzo et al. 2001, Bilenca and Miñarro 2004). Although the effect of agricultural intensification and homogenization of the landscape toward cropland on the avifauna of the Pampas of central Argentina will depend on the sensitivity and plasticity of each species (Fraga et al. 1998, Fernández et al. 2003, Fraga 2003, Di Giacomo and Di Giacomo 2004, Filloy and Bellocq 2006, 2007), we found that the distributions of most specialized grassland birds have declined over the same period in which large areas of our study area have been converted to intensive crop production. We believe that similar trends will be found for rarer and more endangered grassland specialists inhabiting the Pampas, for example, species that were not included in our statistical analyses like the Greater Rhea (Rhea americana), Elegant Crested-Tinamou (Eudromia elegans multiguttata), Bay-capped Wren-Spinetail (Spartonoica maluroides), Hudson's Canastero (Asthenes hudsoni), and Bearded Tachurí (Polystictus pectoralis, AOP/ SADS 2008). Overall, we expect further changes in land management towards high-intensity crop production will reduce distributions of grassland species in the Pampas even more. These findings emphasize the need for conservation actions for grassland birds in the Pampas (Di Giacomo et al. 2007), along with continuing programs of bird monitoring in the rural landscape (Bilenca et al. 2008, Schrag et al. 2009).

\section{ACKNOWLEDGMENTS}

We thank Lucas and Carlos Leveau for their assistance during field work and Juan Pablo Isacch, Juan Ignacio Areta, and Rosendo Fraga for useful comments on an early version of the manuscript. We appreciate the editorial support provided by Luciano N. Naka and 
Catherine L. Bechtoldt, from the program of editorial assistance. We are grateful to the Servicio Meteorológico Nacional (SMN, Argentina), for providing rainfall data. This study was funded by the Consejo Nacional de Investigaciones Científicas y Técnicas (CONICET Argentina), Universidad de Buenos Aires (grants UBACyT X282 and X406), and Instituto Nacional de Tecnología Agropecuaria (INTA Argentina; PNECO 1302).

\section{LITERATURE CITED}

Aide, T. M., AND H. R. GRAU. 2004. Globalization, migration and Latin American ecosystems. Science 305:1915-1916.

Aizen, M. A., L. A. Garibaldi, And M. Dondo. 2009. Expansión de la soja y diversidad de la agricultura Argentina. Ecología Austral 19:45-54.

AOP/SADS. 2008. Categorización de las aves de la Argentina según su estado de conservación. Informe de Aves Argentinas/ AOP y Secretaría de Ambiente y Desarrollo Sustentable, Buenos Aires.

Askins, R. A., F. Chávez-Ramírez, B. C. Dale, C. A. HaAs, J. R. HERKERT, F. L. KNOPF, AND P. D. VicKerY. 2007. Conservation of grassland birds in North America: understanding ecological processes in different regions. Ornithological Monographs 64:1-46.

AzPIROZ, A. B., AND J. G. Blake. 2009. Avian assemblages in altered and natural grasslands in the northern campos of Uruguay. Condor 111:21-35.

BARrows, W. B. 1883. Birds of the lower Uruguay. Bulletin of the Nuttall Ornithological Club 8:82-143.

Baldi, G., And J. M. Paruelo. 2008. Land use and land cover dynamics in South American temperate grasslands. Ecology and Society 13:6.

Benton, T., J. VickeRY, AND J. WiLSON. 2003. Farmland biodiversity: is habitat heterogeneity the key? Trends in Ecology and Evolution 18:182-188.

Bibby, C. J., N. D. Burgess, D. A. Hill, and S. H. Mustoe. 2000. Bird census techniques. Academic Press, San Diego.

BilenCA, D. N., AND F. O. MiñARro. 2004. Identificación de áreas valiosas de pastizal (IVPs) en las pampas y campos de Argentina, Uruguay y sur de Brasil. Fundación Vida Silvestre Argentina, Buenos Aires.

Bilenca, D. N., C. M. GonzÁlez-Fischer, P. Teta, And M. Zamero. 2007. Agricultural intensification and small mammal assemblages in agroecosystems of the Rolling Pampa, central Argentina. Agriculture, Ecosystem and Environment 121:371-375.

Bilenca, D. N., M. Codesido, and C. M. GonzÁlez Fischer. 2008. Cambios en la fauna pampeana. Ciencia Hoy 18:8-17.

BirdLifE InTERNATIONAL. 2004. Birds in the European Union: a status assessment. BirdLife International, Wageningen, the Netherlands.

BirdLifE InTERnATIONAL. 2008. The BirdLife checklist of the birds of the world, with conservation status and taxonomic sources. BirdLife International, Cambridge, UK.

Brook, B. W., N. S. SodHI, AND P. K. L. NG. 2003. Catastrophic extinctions follow deforestation in Singapore. Nature 24:420-423.

CAPlat, P., AND J. Fonderflick. 2009. Area mediated shifts in bird community composition: a study on a fragmented Mediterranean grassland. Biodiversity and Conservation 18:2979-2995.

Codesido, M., C. M. GonZÁlez-Fischer, AND D. N. Bilenca. 2008. Asociaciones entre diferentes patrones de uso de la tierra y ensambles de aves en agroecosistemas de la región pampeana, Argentina. Ornitología Neotropical 19:575-585.

Codesido, M., And R. M. Fraga. 2009. Distributions of threatened grassland passerines of Paraguay, Argentina and Uruguay, with new locality records and notes on their natural history and habitat. Ornitología Neotropical 20:585-595.
Cozzani, N., AND S. Zalba. 2009. Estructura de la vegetación y selección de hábitats reproductivos en aves del pastizal pampeano. Ecología Austral 19:35-44.

Daguerre, J. B. 1936. Sobre nidificación de las aves de la provincia de Buenos Aires. Hornero 6:280-288.

DE LA PeÑA, M. R. 2005. Reproducción de las aves Argentinas (con descripción de pichones). LOLA, Buenos Aires.

Di Giacomo, A. S., AND A. G. Di Giacomo. 2004. Extinción, historia natural y conservación de las poblaciones del yetapá de collar (Alectrurus risora) en Argentina. Ornitología Neotropical 15:145-157.

Di Giacomo, A. S., V. De Francesco, And E. G. Coconier. 2007. Áreas de importancia para la conservación de la aves en la Argentina. Aves Argentinas, Buenos Aires.

Di Giacomo, A. S., And J. Lopez de CASEnAVe. 2010. Use and importance of crop and field-margin habitats for birds in a neotropical agricultural ecosystem. Condor 112:283-293

Doering, A., And P. G. Lorentz. 1879. Diario de los miembros de la comisión científica de la expedición de 1879. Reprinted 1937. Comisión Nacional Monumento al Tte. Gral. Julio A. Roca, Buenos Aires.

Donald, P. F., R. E. Green, And M. F. Heath. 2001. Agricultural intensification and the collapse of Europe's farmland bird populations. Proceedings of the Royal Society of London B 268:25-29.

Donald, P. F., F. J. SANDERson, I. J. Burnfield, And F. P. J. VAN Bommel. 2006. Further evidence of continent-wide impacts of agricultural intensification on European farmlands birds, 1990-2000. Agriculture, Ecosystem and Environment 116:189116.

Fernández, G., G. Posse, V. Ferretti, and F. Gabelli. 2003. Bird-habitat relationship for the declining Pampas Meadowlark populations in the southern Pampas grasslands. Biological Conservation 115:139-148.

Filloy, J., AND M. I. BELlocQ. 2006. Spatial patterns of Sporophila (seedeater) abundance in the southern neotropics: contrasting agricultural development and geographical position. Biodiversity and Conservation 15:3329-3340.

Filloy, J., AND M. I. BellocQ. 2007. Patterns of bird abundance along the agricultural gradient of the Pampean region. Agriculture, Ecosystem and Environment 120:291-298.

Foley, J. A., R. Defries, G. P. Asner, C. Barford, G. Bonan, S. R. Carpenter, F. S. Chapin, M. T. Coe, G. C. Daily, H. K. Gibbs, J. H. Helkowski, T. Holloway, E. A. Howard, C. J. Kucharik, C. Monfreda, J. A. I. Patz, C. Prentice, N. Ramankutty, and P. K. SNYDER. 2005. Global consequences of land use. Science 309:570-574.

FraGA, R. M. 2003. Distribution, natural history and conservation of the Black-and-white Monjita (Heteroxolmis dominicana) in Argentina, a species vulnerable to extinction. Ornitología Neotropical 14:145-156.

Fraga, R. M., G. Pugnali, and H. Casañas. 1998. Natural history and conservation status of the endangered Saffron-cowled Blackbird (Xanthopsar flavus) in Argentina. Bird Conservation International 8:255-267.

GASTON, K. J. 1994. Measuring geographic range sizes. Ecography 17:198-205.

Ghersa, C. M., AND R. J. C. LeÓN. 1999. Successional changes in agroecosystems of the Rolling Pampa, p. 487-502. In L. R. Walker [ED.], Ecosystems of the world 16. Ecosystems of disturbed ground. Elsevier, New York.

Herzon, I., A. Aunins, J. Elts, And Z. Preiks. 2008. Intensity of agricultural land-use and farmland birds in the Baltic states. Agriculture, Ecosystem and Environment 125:93-100.

HolmberG, E. L. 1883/84. Resultados científicos, especialmente zoológicos y botánicos de los tres viajes llevados a cabo en 1881, 
1882 y 1883 a la sierra de Tandil. Aves. Actas de la Academia Ciencias de Córdoba 5:73-92.

INDEC (Instituto Nacional de Estadística y Censos de la República Argentina). 2006. Censo nacional agropecuario 2002: resultados generales, 1st ed. INDEC, Buenos Aires.

Krapovickas, S., AND A. S. Di Giacomo. 1998. Conservations of pampas and campos grasslands in Argentina. Parks 8:47-53.

LART-MAAYP [ONLINE]. 2004. Estimación de áreas y distribución de las diferentes clases de cobertura de suelo durante el período inverno-primaveral para la provincia de Buenos Aires. Laboratorio de Análisis Regional y Teledetección, Ministerio de Asuntos Agrarios y Producción, Gobierno de la Provincia de Buenos Aires, Buenos Aires. <http://www.agro.uba.ar/users/lart/ estimacionesagricolas/>

LEÓN, R. J. C. 1991. Geographic limits of the region, geomorphology and geology, regional subdivisions, floristic aspects, description of the vegetation, p. 369-387. In R. T. Coupland [ED.], Natural grasslands, introduction and Western Hemisphere. Elsevier, Amsterdam.

MartíneZ-Ghersa, M. A., AND C. M. GHersa. 2005. Consecuencias de los recientes cambios agrícolas. Ciencia Hoy 15:37-45.

Mc Laughlin, A., AND P. Mineau. 1995. The impact of agricultural practices on biodiversity. Agriculture, Ecosystem and Environment 55:202-212.

Møller, A. P., AND M. D. Jennions. 2001. Testing and adjusting for publication bias. Trends in Ecology and Evolution 16:580-586.

NAROSKY, T., AND A. G. Di GiACOMO. 1993. Las aves de la provincia de Buenos Aires: Distribución y estatus. Asociación Ornitológica del Plata, Vázquez Mazzini Editores, Buenos Aires.

NAROSKY, T., AND S. SALVADOR. 1998. Nidificación de las aves argentinas. Tyrannidae. Asociación Ornitológica del Plata, Buenos Aires.

Narosky, S., R. Fraga, And M. De la PeÑa. 1983. Nidificación de las aves argentinas. Dendrocolaptidae y Furnaridae. Asociación Ornitológica del Plata, Buenos Aires.

PECBMS (Pan-European Common Bird Monitoring Scheme). 2009. The state of Europe's common birds 2008. CSO/RSPB, Prague, Czech Republic.

PeH, K. S. H. 2007. Potential effects of climate change on elevational distributions of tropical birds in Southeast Asia. Condor 109:437-441.

Ridgely, R. S., AND G. Tudor. 2009. Field guide to the songbirds of South America: the passerines. University of Texas Press, Austin.

Robinson, R., And W. J. Sutherland. 2002. Post-war changes in arable farming and biodiversity in Great Britain. Journal of Applied Ecology 39:157-176.
RoDriguez-Estrella, R. 2007. Land use changes affect distributional patterns of desert birds in the Baja California peninsula, Mexico. Diversity and Distributions 13:877-889.

Rodríguez Mata, J., F. Erize, and M. Rumboll. 2006. Aves de Sudamérica: no Passeriformes. Desde ñandúes a carpinteros. Letemendía, Buenos Aires.

Schrag, A. M., M. E. Zaccagnini, N. Calamari, and S. CanaVELLI. 2009. Climate and land-use influences on avifauna in central Argentina: broad-scale patterns and implications of agricultural conversion for biodiversity. Agriculture, Ecosystem and Environment 132:135-142.

Siegel, S., And N. Castellan. 1988. Nonparametric statistics for the behavioral sciences, 2nd edition. McGraw-Hill International, Singapore.

Siriwardena, G. M., S. Baillie, S. Buckland, R. Fewster, J. Marchant, AND J. Wilson. 1998. Trends in the abundance of farmland birds: a quantitative comparison of smoothed common birds census indices. Journal of Applied Ecology 35:24-43.

Soriano, A., R. J. C. León, O. E. Sala, R. S. Lavado, V. A. Deregibus, M. A. Cahuepé, O. A. Scaglia, C. A. Velázquez, and J. H. LEMCOFF. 1991. Río de la Plata grasslands, p. 367-407. In R.T. Coupland [ED.], Natural grasslands: introduction and Western Hemisphere. Elsevier, Amsterdam.

SzPeiner, A., M. Martínez-Ghersa, and C. Ghersa. 2007. Agricultura pampeana, corredores biológicos y biodiversidad. Ciencia Hoy 17:38-43.

Tubaro, P. L., AND F. M. Gabelli. 1999. The decline of the Pampas Meadowlark: difficulties of applying IUCN criteria to neotropical grassland birds. Studies in Avian Biology 19:250-257.

Vega, E., G. BAldi, E. JobbÁgy, And J. M. PARuelo. 2009. Land use change patterns in the Río de la Plata grasslands: the influence of phytogeographic and political boundaries. Agriculture, Ecosystem and Environment 134:287-292.

Vickery, P., P. Tubaro, J. Silva, B. Peterjohn, J. Herkert, and R. Cavalcanti. 1999. Conservation of grassland birds in the Western Hemisphere. Studies in Avian Biology 19:2-26.

Viglizzo, E. F., F. A. Lertora, A. J. Pordomingo, J. N. Bernardos, Z. E. Roberto, ANd H. Del Valle. 2001. Ecological lessons and applications from one century of low-external input farming in the pampas of Argentina. Agriculture, Ecosystems and Environment 81:65-81.

WARNER, R. E. 1994. Agricultural land use and grassland habitat in Illinois: future shock for Midwestern birds? Conservation Biology 8:147-156. 